\title{
Campylobacter pylori, duodenal ulcer, and gastric metaplasia: possible role of functional heterotopic tissue in ulcerogenesis
}

\author{
J CARRICK, A LEE, S HAZELL, M RALSTON, AND G DASKALOPOULOS
}

From the Bruce Hall Unit of Gastroenterology, St Vincent's Hospital, Sydney and School of Microbiology, University of New South Wales, Sydney, Australia

SUMmary Multiple pinch biopsies were taken from the duodenum and antrum of 137 subjects (46 active duodenal ulceration; 44 healed ulcers; 47 'normals'), and examined for the presence and grade of gastritis, gastric metaplasia, and Campylobacter pylori. These factors, as well as age, sex, cigarette, and anti-inflammatory agent intake were evaluated as possible risk factors for duodenal ulceration. Pentagastrin induced Congo Red staining of the duodenal bulb was performed in an additional 43 cases, to determine the presence of functioning parietal cells in the duodenum. Ninety eight per cent of patients with duodenal infection with $C$ pylori had active or healed duodenal ulcers. Bacteria were confined to areas of gastric metaplasia which was always infiltrated with inflammatory cells. The metaplastic tissue was usually superficial in type, although patients had $C$ pylori associated with heterotopic tissue: this has not been previously described. Congo Red staining of the duodenal bulb showed that functioning endogenous acid producing tissue could be found most often at the edges of duodenal ulcers, but also in non-ulcer subjects. Cigarette smoking, age, sex, and ingestion of non-steroidal anti-inflammatory agents were not to be found to be significant risk factors for duodenal ulceration. In contrast, the presence of duodenal infection with $C$ pylori proved to be a strong risk factor for duodenal ulceration $(R R=51)$, together with gastric metaplasia $(R R=6 \cdot 2)$, and antral $C$ pylori infection $(\mathrm{RR}=\mathbf{7 \cdot 6})$. These data identify duodenal infection with $C$ pylori as the strongest risk factor for development of duodenal ulceration. Our finding of endogenous acid production around the edges of duodenal ulcers suggests an active role for parietal cells in the duodenum. We postulate a synergistic role for duodenal $C$ pylori and endogenous acid production in the development of duodenal ulceration.

The spiral bacterium Campylobacter pyloridis is now clearly established as the major causative agent of non autoimmune gastritis. ' 2 The part played by this organism in peptic ulceration, however, remains controversial. Many authors have noted an extremely high association between $C$ pylori infection in the antrum and duodenal ulceration, leading to suggestions that this bacterium may play an active role in ulcerogenesis. ${ }^{3}$

Address for correspondence: Dr J Carrick. Bruce Hall, Dept Gastroenterology, St Vincent's Hospital, Sydney. Australia, 2010.

Accepted for publication 27 Octoher 1988.
Steer initially observed that bacteria in the duodenum, now known to be $C$ pylori, were always associated with gastric type cells. Wyatt ${ }^{56}$ in a study on pinch biopsies has recently confirmed that gastric metaplasia is an essential prerequisite for duodenal infection by $C$ pylori. She noted that the organism was always seen in association with superficial gastric metaplasia - that is, mucus producing gastric epithelial cells.

Heterotopic tissue-that is, gastric metaplastic tissue containing chief cells and parietal cells-was only rarely seen in the duodenum by Wyatt. This is in contrast with two studies on wholly resected duo- 
Table 1 Patient profiles for subjects undergoing gastroduodenal biopsy

\begin{tabular}{|c|c|c|c|c|c|}
\hline $\begin{array}{l}\text { Ulcer } \\
\text { status }\end{array}$ & $\begin{array}{l}\text { Subjects } \\
n(\%)\end{array}$ & $\begin{array}{l}\text { Mean age } \\
\text { (range) } \\
\text { (years) }\end{array}$ & $\begin{array}{l}\text { M:F ratio } \\
(\% \text { male })\end{array}$ & $\begin{array}{l}\% \text { smokers } \\
\text { (range no. } \\
\text { smoked per } \\
\text { day) }\end{array}$ & $\begin{array}{l}\text { Regular } \\
\text { NSAID } \\
\text { intake }\end{array}$ \\
\hline $\begin{array}{l}\text { No ulcer } \\
\text { (no ulcer } \\
\text { history) }\end{array}$ & $47 / 137(35)$ & $41(15-72)$ & $3 \cdot 6: 1(68)$ & $58(10-40)$ & 17 \\
\hline $\begin{array}{l}\text { Healed } \\
\text { ulcer }\end{array}$ & $44 / 1.37(32)$ & $41(21-63)$ & $2 \cdot 8: 1(70)$ & $59(10-40)$ & 9 \\
\hline $\begin{array}{l}\text { Active } \\
\text { ulcer }\end{array}$ & $46 / 137(34)$ & $40(19-63)$ & $2 \cdot 2: 1(78)$ & $47(15-50)$ & 15 \\
\hline
\end{tabular}

denal bulbs. In one necropsy study from Japan involving 118 individuals without gastric and duodenal disease, 27 subjects $(22 \%)$ had clusters of parietal cells in the proximal duodenum. ${ }^{7}$ Johansen and Hansen ${ }^{\times}$while examining specimens of duodenum resected at operation found parietal cell heterotopia in $10 \%$ of those with gastric cancer compared with $52 \%$ with duodenal ulcer. It appeared important therefore to determine the pathology of duodenal ulceration particularly with respect to the presence of parietal cells, their potential for endogenous acid production and the association of this tissue with $C$ pylori.

The success of histamine 2 receptor antagonists $\left(\mathrm{H}_{2}\right.$ antagonists $)$ and vagotomy in treating duodenal ulcer underlines the importance of acid in the pathogenesis of this condition. ${ }^{410}$ This appears to be in conflict with those authors who suggest $C$ pylori to be the cause of duodenal ulceration. ${ }^{3}$ A synergistic role for both $C$ pylori and acid in ulcer initiation and maintenance has not been investigated.

This study reports on the histology and microbiology of the duodenal bulb and stomach of 90 ulcer patients and 47 non-ulcer patients. A further 43 patients underwent an endoscopic Congo Red test. Using multivariate logistic regression analysis of these results, $C$ pylori infection of the duodenum is shown to be an extremely high risk factor for duodenal ulcer disease. Gastric metaplastic tissue is essential for infection of the duodenum and functional heterotopic tissue may be important in the pathogenesis of ulcer formation.

\section{Methods}

\section{SUBJECTS}

This study was approved by St Vincent's Hospital Ethics Committee, and written informed consent was obtained from 137 subjects, comprising 46 with active duodenal ulceration, 44 with healed duodenal ulcers and 47 with macroscopically normal duodenal bulbs and no current or previous history of duodenal ulcer disease (Table 1). A minimum of two 'pinch' biopsies were taken from the duodenal bulb and gastric antrum of each subject at upper gastrointestinal endoscopy. All the subjects with a 'normal' duodenum had presented for endoscopy with indications other than ulcer symptoms - for example, dysphagia, symptoms of gastro-oesophageal reflux, or iron deficiency anaemia. The average age of the ulcer group was 42.9 years (range 19-66) and of the nonulcer group $42 \cdot 1$ years (range 15-72). There were no significant differences with regard to sex, smoking or the ingestion of non-steroidal anti-inflammatory drugs.

HISTOLOGICAL STUDIES

Sections of biopsy tissue were stained with haematoxylin and eosin, examined to determine the number of foci of gastric metaplasia and graded for the presence of mononuclear cells ('chronic gastritis') and polymorphonuclear leucocytes ('active gastritis'). " The grades were as follows:

\section{Chronic gastitis}

$0=$ nil mononuclear cells,

I =only occasional inflammatory cells present in patchy distribution; Mononuclear cells not generally confluent;

II = inflammatory cell infiltration intermediate between grades one and three;

$I I I=$ very dense infiltration of mononuclear cells throughout the entire section with the presence of lymphoid follicles.

\section{Active gastritis}

$0=$ nil polymorphonuclear leucocytes;

I =only occasional inflammatory cells present in patchy distribution. Polymorphonuclear cells not seen in every high power field;

II = inflammatory cell inflitration intermediate between grades one and three;

III = very dense infiltration of inflammatory cells throughout the entire section and/or gland abscesses with polymorphonuclear cells.

Warthin-Starry stains were used to assess the presence and grade of $C$ pylori organisms (0-III) ${ }^{11}$

$0=$ no bacteria seen;

I =occasional bacteria present but not seen in every high power field;

II = bacterial numbers intermediate between grades one and three;

$\mathrm{III}=$ numerous bacteria in all fields, usually confluent and covering the entire mucosal surface.

The grades of gastritis and $C$ pylori infection were assessed by an experienced histopathologist (MR) 
who was unaware of the origin of each specimen. Periodic acid Schiff (PAS) stains were used when necessary to assess the extent of gastric metaplasia more easily. Metaplastic tissue was graded as either 'superficial' or 'heterotopic'. Superficial gastric metaplasia was defined as ectopic gastric mucus producing epithelial cells, whilst heterotopic gastric metaplasia contained fully developed fundic tissue with chief cells and parietal cells. Rapid biopsy urease testing" of adjacent biopsy specimens was performed in all cases as confirmation of $C$ pylori infection.

ACID SECRETING STUDIES

Acid production in the duodenal bulb was assessed in 43 subjects ( 36 with duodenal ulcer disease and seven with no history of peptic ulceration) by the method of Ikeda et $a l^{12}$ as modified by Donoghue..$^{13}$ Two hundred and fifty micrograms of pentagastrin (ICI, UK) were injected intramuscularly 30 minutes before the endoscopic examination. At endoscopy, $10 \mathrm{ml}$ $0.3 \%$ Congo Red in $0.5 \%$ sodium bicarbonate was sprayed over the duodenal bulb. Acid production by duodenal mucosa was considered to be present if the solution changed from a bright red colour to blue/ black.

\section{STATISTICAL. ANALYSIS}

The variable of interest (response) was the presence or absence of duodenal ulcer disease. Risk variables evaluated were superficial and heterotopic gastric metaplasia, antral and duodenal $C$ pylori infections, age, gender, non-steroidal anti-inflammatory drug, and cigarette consumption. The significance of the various possible risk factors on the presence of duodenal ulcer disease was determined using step wise multivariate logistic regression by Dr V Gebski of the Department of Biostatistics, Macquarie University, Sydney, Australia using the methods outlined by Cox. ${ }^{1+}$

\section{Results}

Ninety eight per cent of subjects with duodenal $C$ pylori infection had either active or healed duodenal ulcers. Eighty three per cent of those with active ulcers and $73 \%$ of those with healed ulcers had duodenal infection with $C$ pylori (Table 2). The specificity of $C$ pylori association for gastric metaplasia is shown in Figure 1. There is an area in this section of superficial type gastric cells adjacent to small intestinal surface cells. The bacteria are only associated with gastric type cells, and abruptly cease at the junction of gastric and small intestinal epithelial cells. The gastric metaplasia may be a single cell layer, sometimes mixed with intestinal cells. $C$ pylori is clearly able to colonise these single cell layers. In this same section, the bacteria are also seen to colonise the full thickness gastric metaplasia in very large numbers.

The gastric metaplasia seen in biopsies was mostly superficial (Table $2 \mathrm{~b}$ ). In $11 \%$ of the ulcer patients, however, and in $2 \%$ of non-ulcer patients full thickness gastric metaplasia of the heterotopic type was observed. This heterotopia was always focal. Gastric metaplasia was detected commonly in both ulcer and non-ulcer patients (Table $2 \mathrm{~b}$ ), although the incidence

Table 2 (a) Grades of inflammation and $\mathrm{C}$ pylori in the antrum and duodenum of 137 ulcer and non ulcer subjects.

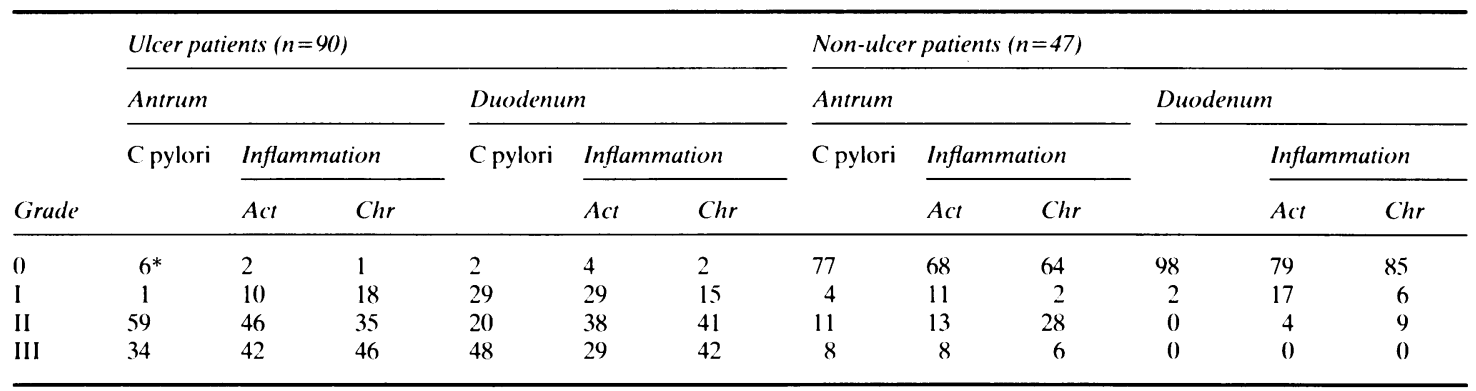

$*=\% ;$ Act $=$ active $:$ Chr $=$ chronic

(b) Results of histopathological assessment of biopsy specimens

\begin{tabular}{llcc}
\hline Ulcer status & Superficial metaplasia & Heterotopic metaplasia & Duodenal C pylori \\
\hline Active ulcer & $42 / 46(91 \%)$ & $5 / 46(11 \%)$ & $38 / 46(83 \%)$ \\
Healed ulcer & $41 / 44(93 \%)$ & $1(2 \%)$ & $32 / 44(73 \%)$ \\
No ulcer & $15 / 47(32 \%)$ & $(0 / 47(0 \%)$ & $42 / 44(95 \%)$ \\
\hline
\end{tabular}




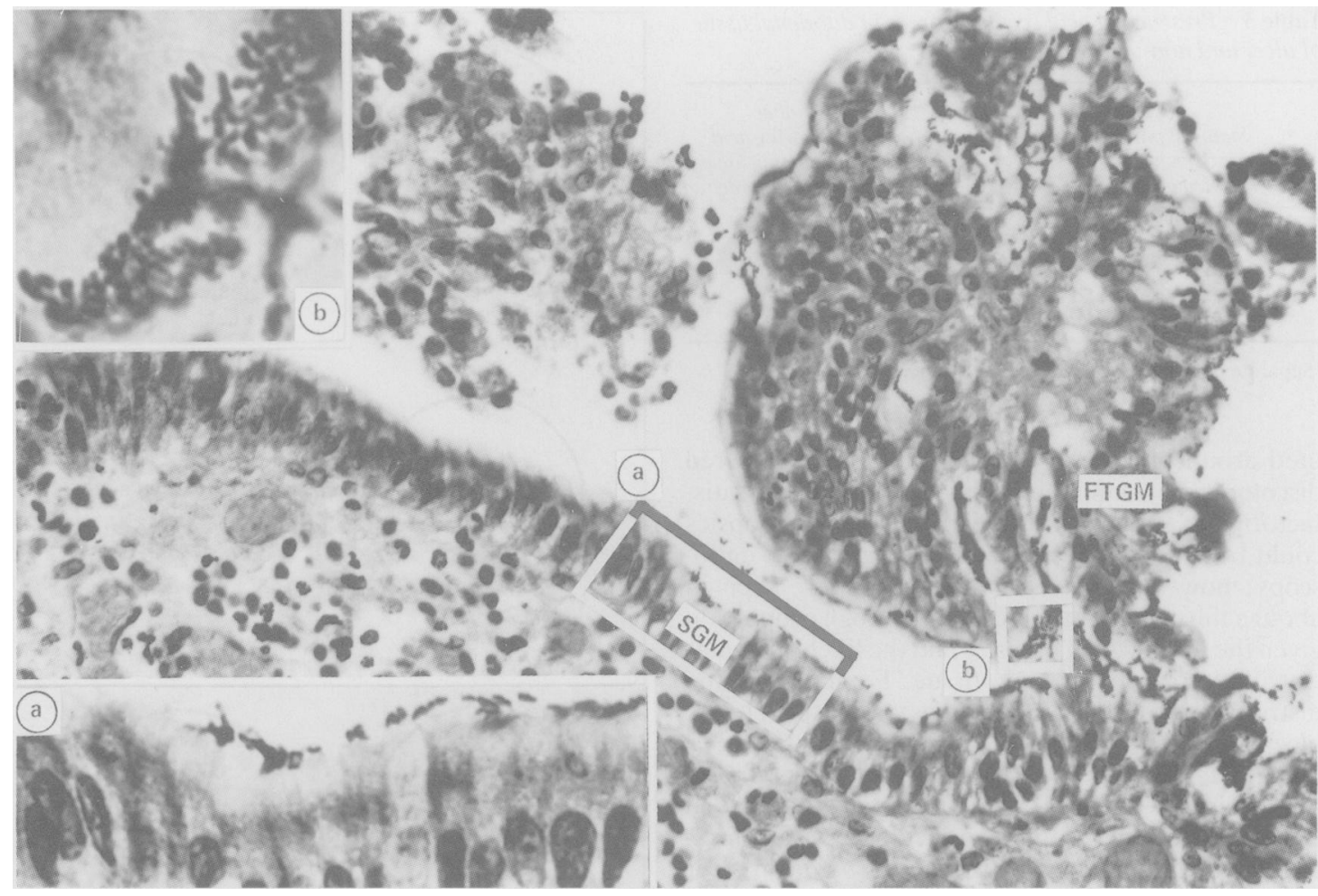

Fig. 1 Warthin Starry stain of a duodenal biospy from a patient with a duodenal ulcer. S( $; M=$ superficial gastric me'taplasia. FTGM = full thickness gastric metaplasia (heterotopia). Inset (a) An area of superficial gastric metaplasia and inte'stinal tissue' with C pylori only associated with the surface of the single layer of gastric type epithelium. Inset (b) He'avy ('pylori infection within an area of full thickness gastric metaplasia.

was higher in those with active duodenal ulcer disease, $91 \% v 32 \%(\mathrm{p}<0 \cdot(01)$. Patients with healed ulcers also had a very high incidence of gastric metaplasia $(95 \%)$.

The grades of gastritis and $C$ pylori infection of the duodenal and antral biopsies from the patients studied are shown in Table 2. Antral $C$ pylori infection was found in close association with duodenal ulceration. Ninety three per cent of those with active duodenal ulceration and $95 \%$ of those with healed ulceration had evidence of $C$ pylori infection. In contrast, only $23 \%$ of those with no history of duodenal ulceration had antral $C$ pylori infection $\left(\mathrm{p}<0.001 \chi^{2}\right.$ analysis). Although our grading system for $C$ pylori was only semiquantitative it appeared that the actual concentration of $C$ pylori in the duodenum of ulcer patients was less than that seen in the antrum of the same patients. Only $71 \%$ of the ulcer patients had high grades (II and III) of C pylori infection in the duodenum compared with $93 \%$ in the antrum.

The association of $C$ pylori and both active and chronic inflammation is clearly demonstrated (Table 2 a). In the antra of ulcer patients $93 \%$ had significant numbers of $C$ pylori (> grade II), $88 \%$ had significant polymorphonuclear cell accumulation and $81 \%$ significant mononuclear cells. Comparative figures in the duodenum for the ulcer patients were $68 \%, 67 \%$, $83 \%$.

INVESTIGATION OF FUNCTIONAI. HETIEROTOPIC TISSUE:

Congo red staining of the duodenal bulb in a further 43 patients showed that functioning endogenous acid producing tissue can be present independently of the presence of ( pylori infection (Table 3). All three patients with gastric metaplasia but no (' pylori infection showed a colour change from red to black indicative of acid secretion. The majority of specimens showing gastric metaplasia and coexisting C pylori infection changed from red to black (26/36). In patients with no areas of gastric metaplasia, there were no acid induced colour changes detected. The areas of acid secretion were focal and were distrib- 
Table 3 Presence of acid secreting areas in duodenal tissue of ulcer and non-ulcer patients

\begin{tabular}{llllll}
\hline & & & & \multicolumn{2}{l}{$\begin{array}{l}\text { Sumber } \\
\text { Showing acid }\end{array}$} \\
\cline { 3 - 6 } $\begin{array}{llll}\text { Active } \\
\text { ulcer }\end{array}$ & Healed ulcer Metaplasia & C pylori & $\begin{array}{l}\text { Patients } \\
(n)\end{array}$ & $\begin{array}{l}\text { Hecreting areas } \\
\text { in the duodenum }\end{array}$ \\
\hline+ & - & $+*$ & $+*$ & 23 & 20 \\
- & + & + & + & 13 & 6 \\
- & - & + & - & 3 & 3 \\
- & - & - & - & 4 & 0 \\
\hline
\end{tabular}

*Separate biopsies were taken from all patients for histology.

uted around the ulcers. Because of the Congo red discoloration stained biopsies could not be satisfactorily examined histologically. Where biopsies could be taken from the same area at repeat endoscopy, however, acid secreting cells were seen in about a third of the specimens, a very high proportion given the small size of biopsies and the likely irregular distribution of heterotopic tissue. Examples of the distribution of acid secreting areas with respect to the ulcer site in the duodenal bulb are shown in Figures 2 and 3. The black areas always appeared concentrated to one side of the bulb. The ulcer site was always in this area. Because of the high incidence of colonisation of gastric metaplastic tissue by $C$ pylori in ulcer patients compared with non-ulcer patients, results were analysed to determine the significance of gastric metaplasia and $C$ pylori infection as risk factors in duodenal disease.

STATISTICAL ANALYSIS

The results of step wise logistic regression are shown in Table 4. Gastric metaplasia, antral $C$ pylori infection, and duodenal $C$ pylori infection were shown to be significant predictive factors for duodenal ulceration. By far the strongest risk factor for duodenal ulceration is duodenal $C$ pylori infection (relative risk $=51$ for duodenal $C$ pylori infection compared with eight for antral infection). Age, sex, cigarette smoking, and non-steroidal anti inflammatory drug intake were not found to be significant risk factors in the 90 ulcer patients studied (Table 1).

\section{Discussion}

The cause of duodenal ulceration remains unknown. Various contributory factors, however, have been identified. In our study, we examined age, sex, cigarette consumption, non-steroidal anti-inflammatory intake, gastric metaplasia, antral $C$ pylori infection, and duodenal $C$ pylori infection. The most striking association with duodenal ulceration was duodenal infection with $C$ pylori $(\mathrm{RR}=51)$. We

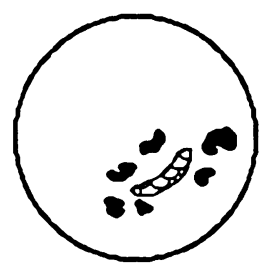

Healed duodenal ulcer treated for C pylori

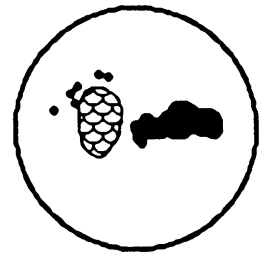

Large active duodenal ulcer

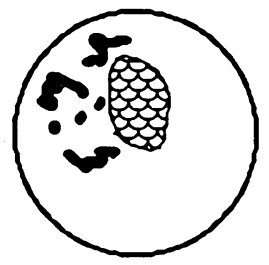

Large active duodenal ulcer
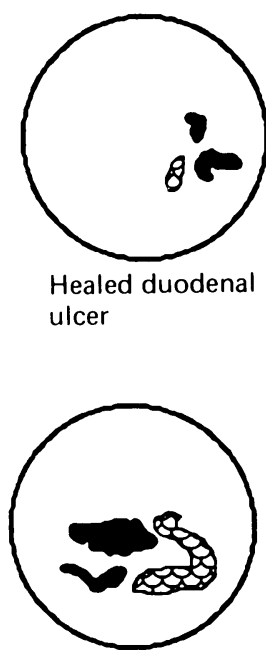

Active duodenal ulcer

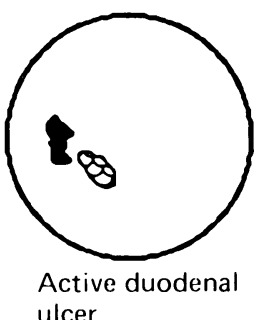

ulcer

\section{Site of ulcer or ulcer scar \\ Area of Congo Red turned black}

Fig. 2 Diagram of the appearance of endoscopic fields from the duodenal bulb of six representative patients after pentagastrin induced Congo red staining.

found only one patient who had duodenal $C$ pylori infection and no history of ulcer disease. If $C$ pylori is demonstrated on duodenal biopsy, the likelihood of ulcer disease is 172:1. This extremely high risk factor strongly supports a role for $C$ pylori, either active or passive, in ulcerogenesis. Thus there is clearly a need to understand more about the association of $C$ pylori with the duodenal tissue.

The histological examination of the biopsies from 137 subjects reported here confirms the association described previously of $C$ pylori and gastric metaplasia in the duodenum. This association is specific for the surface of the gastric type epithelial cell. Colonisation could be clearly seen on areas of a single 


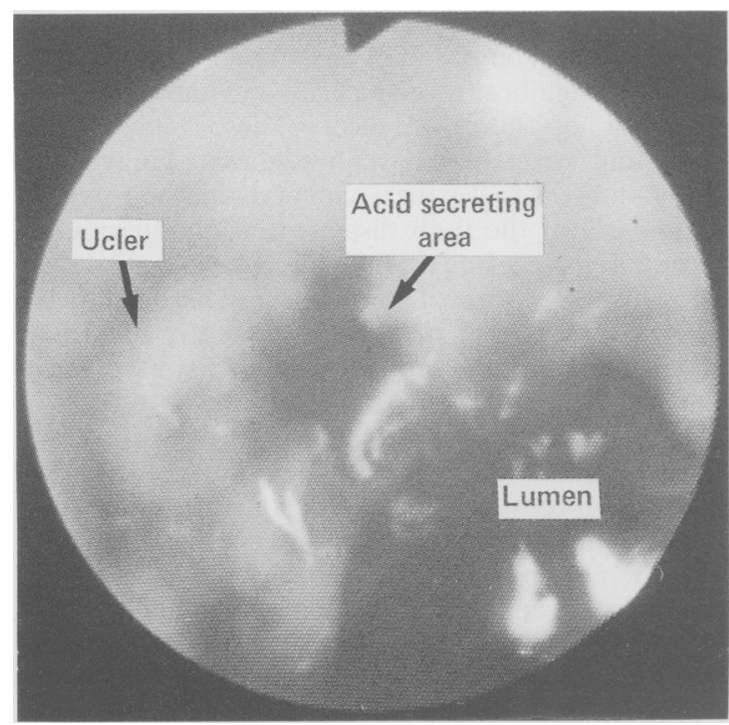

Fig. 3 Photograph of an endoscopic field of a patient with an active duodenal ulcer and biopsy proven $\mathrm{C}$ pylori infection and gastric metaplasia showing a large area of Congo red stained acid secreting tissue.

mucus producing cell layer. This bacterium appears to be adapted to the ecological niche of gastric mucus. ${ }^{15}$ Thus, the specificity of association could either be as a result of the type of mucus produced by these cells or to the presence of specific receptors on the cell surface at the intercellular junction. In all specimens where $C$ pylori was found associated with metaplasia, an underlying infiltration of polymorphonuclear cells was noted. This is equivalent to the situation in the stomach, where the presence of $C$ pylori is always associated with active gastritis, and is considered to be the cause of the inflammation. The histological gradings on the patients reported here confirmed the association of antral $C$ pylori infection with active chronic gastritis.

\section{Table 4 Statistical interpretation of biopsy data}

(i) Using multivariate logistic regression, the significance of a given factor in duodenal ulcer disease is as follows:

Gastric metaplasia $\quad \mathrm{p}=\mathbf{0} \cdot(0) 36$

Antral Cpylori infection $\quad \mathrm{p}=0.063$

Duodenal $C$ pylori infection $\mathrm{p}=0.001$

(ii) Significant risk factors in duodenal ulcer disease

\begin{tabular}{lcrl} 
& Relative & Odds & Confidence \\
Factor assessed & risk & radio & limits \\
Gastric metaplasia & $6 \cdot 22\left(0 \cdot 82^{*}\right)$ & $21 \cdot 2$ & $1 \cdot 1-27 \cdot 8$ \\
Antral C pylori infection & $7.67(0.75)$ & $55 \cdot 6$ & $0 \cdot 93-17 \cdot 3$ \\
Duodenal C pylori infection & $51 \cdot(0)(1 \cdot 01)$ & $171 \cdot 9$ & $4 \cdot 8-341 \cdot 2$ \\
\hline
\end{tabular}

*Standard error.
Gastric metaplasia has been found in all parts of the gastrointestinal and biliary tracts, from the oesophagus to the rectum, and even in the pancreas and gall bladder. ${ }^{10-1 x}$ According to Taylor and Perera, ${ }^{112}$ " there are two types of gastric metaplasia, (i) superficial and (ii) heterotopic. Each of these types can be further classified as either congenital or acquired. Superficial gastric metaplasia contains no fundic cells and purely involves the epithelial lining cells. Heterotopic gastric metaplasia contains parietal and chief cells. The very well structured gastric heretopic tissue described by James $e t l^{\prime \prime}$ is probably congenital in origin. The more patchy, disorganised full thickness metaplasia described by Hoedemaker,, 2 and the superficial type described by Taylor $^{21}$ and Wyatt $^{6}$ are more likely to be acquired later in life. It is these two latter types of gastric metaplasia that are found so frequently in association with duodenal ulceration, and which $C$ pylori so commonly infects.

Consideration of the type and function of the metaplastic tissue associated with $C$ pylori and the ulcer itself is important in consideration of the possible mechanisms of ulcerogenesis. Using single 'pinch' biopsies, Wyatt" noted a very low incidence of gastric heterotopia, suggesting that functioning gastric tissue plays little role in ulcer formation. Studies looking at whole duodenal bulbs ${ }^{7 \times}$ suggest, however, that heterotopia is very common, especially in duodenal ulcer disease $(52 \%)$. Willis ${ }^{1 \mathrm{~h}}$ has shown that heterotopic tissue is often functional tissue. In the present study, at least two 'pinch' biopsies were taken from the edges of ulcers, thus increasing the frequency of detection of heterotopia. The pentagastrin induced Congo red studies support the concept that gastric heterotopia is more common than can be shown by 'pinch' biopsy alone, and that this tissue may contain functioning parietal cells.

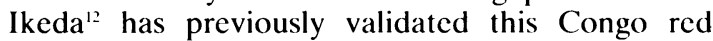
method which identifies acid secreting areas of heterotopia. Because acid is considered such an important ingredient for ulcer formation, it is important to determine how often duodenal ulceration is associated with functioning areas of metaplastic tissue. By definition, the tissue central to an ulcer is destroyed, and thus the very pathology which we are seeking may have eroded by the ulcer itself.

Other factors (as yet unidentified) may induce metaplasia, or it may be congenital. As it is such a common finding, even among the normal population - that is, Kreunig found superficial gastric metaplasia in $64 \%$ of a group of healthy volunteers, ${ }^{23}$ it is possible that gastric metaplasia is simply a variation of normal.

One important factor in ulcerogenesis could be the transmission of the $C$ pylori from the antrum to areas 
of gastric metaplasia within the duodenum. It is important to note that four patients who had gastric metaplasia in the duodenum but $C$ pylori confined to the antrum had no history of duodenal ulceration that is, some subjects can have a longstanding antral $C$ pylori infection and gastric metaplasia in the duodenum which for some reason does not become infected. Other factors to be considered could relate to blood flow or other anatomical differences at the ulcer site. Why is it that ulcers recur at the same site? Conversely, can duodenal ulceration arise in areas of strictly superficial type gastric metaplasia? Acid induced tissue damage is an essential path towards ulcer formation. The question is, does $C$ pylori catalyse this damage, and if so how? If the association is restricted to superficial metaplasia only, then one has to postulate that the presence of the organism changes the local environment in a way that facilitates damage by gastric acid - for example, by changing the properties of intestinal mucus at the site. ${ }^{3}$ If ulcerogenesis occurs at sites of full thickness metaplasia, then the hydrogen ion back diffusion hypothesis proposed previously could be relevant. According to this hypothesis, the high urease activity of the $C$ pylori on the surface of the tissue alters the local milieu such that the normal process of hydrogen ion transport to the lumen is disturbed. ${ }^{24}$ This results in the back diffusion of hydrogen ions into the tissue. These submucosal hydrogen ions may initiate tissue damage. Thus, endogenous duodenal acid secretion may contribute to the pathology of duodenal ulceration. In other words, there may be a syneristic role for duodenal $C$ pylori infection and acid produced at the ulcer site.

Duodenal ulceration is a multifactorial disease. ${ }^{25}$ Family history, blood type, cigarette consumption, non-steroidal anti-inflammatory agents, and hyperacidity have all been identified as possible contributory factors. Any discussion on the role of $C$ pylori in ulcerogenesis has to take these factors into consideration. One possible link is that a number of as yet undefined variables may influence the presence or degree of gastric metaplasia in the duodenum. Wyatt ${ }^{\circ}$ has suggested that a major factor in the induction of gastric metaplasia is gastric hyperacidity. This is controversial, as a number of studies have indicated that metaplasia is not influenced by hyperacidity. ${ }^{2027}$ Bendtsen et $a l^{28}$ recently found no difference in the mean hydrogen ion activity of 24 hour duodenal $\mathrm{pH}$ for ulcer and on-ulcer subjects. The observation of gastric metaplasia in areas such as pancreas, colon, and gall bladder is further evidence that acid is not required for its development.

In a study of 2350 normal duodenal bulbs Terruzzi ${ }^{29}$ found 13 cases of macroscopic nodules in the duodenal bulb that were found to be hetero- topic areas of well developed gastric mucosa with fundic glands composed of parietal and chief cells in all cases. Significantly eight of 13 had had a previous diagnosis of duodenal ulcer. These findings are consistent with the above hypothesis. Unlike our study, however, Terruzzi claimed that the gastric metaplasia in the bulb disappeared on subsequent biopsy. He suggested that the metaplasia is a delayed type healing process of peptic ulcer. This is unlikely, as both Wyatt and ourselves frequently identified gastric metaplasia in subjects with no history of ulcer disease.

In conclusion, these data identify duodenal C. pylori infection as the strongest risk factor for duodenal ulceration. Our finding of endogenous acid production in the duodenum of some ulcer patients plus the accumulating evidence that ulcer relapse is significantly reduced in duodenal ulcer patients from whom $C$ pylori has been eradicated ${ }^{32-32}$ lend weight to the proposal that $C$ pylori is actively involved in the pathogenesis of duodenal ulceration. Current concepts of duodenal ulceration and factors involved in pathogenesis need to be reappraised in the light of the proposed synergy between $C$ pylori infection and locally secreted acid induced damage.

This work was supported in part by the National Health and Medical Research Council of Australia.

\section{References}

1 Floch MH. Campylobacter pyloridis: identification and clinical significance. Am J Gastroenterol 1987; 82: 358.

2 Morris A, Nicholson G. Ingestion of Campylobacter pyloridis causes gastritis and raised fasting $\mathrm{pH} . \mathrm{Am} \mathrm{J}$ Gastroenterol 1987; 82: 192-9.

3 Marshall BJ, Peptic ulcer: An infectious disease? Hospital Practice 1987: 87-96.

4 Steer HW. Surface morphology of the gastroduodenal mucosa in duodenal ulceration. Gut 1984; 25: 1203-10.

5 Wyatt JI, Rathbone BJ, Dixon MF, Heatley RV. Campylobacter pylori and acid induced gastric metaplasia in the pathogenesisi of duodenitis. J Clin Pathol 1987; 40: 841-8.

6 Wyatt JI, Rathbone BJ, Dixon MF, Heatley RV, Axon ATR. Campylobacter pylori and development of duodenal ulcer. Lancet 1988; i: 118-9.

7 Tominaga K. Distribution of parietal cells in the antral mucosa of human stomachs. Gastoenterology 1975; 69: 1201-7.

8 Johansen AA, Hansen $\mathrm{OH}$. Heterotopic gastric epithelium in the duodenum and its correlation to gastric disease and acid level. Acta Pathol Microbiol Scand 1973; sect A 81: 676-80.

9 Cortot A, Henry-Aman M, Pasis JC, Pappo M. A comparison of ranitidine versus cimetidine in the treatment of acute duodenal ulcer. Gastroenterol Clin Biol 1987; 11: 136-41. 
10) Wise L. Ballinger W. The elective surgical treatment of chronic duodenal ulcer. Surgery 1974; 76: 811-26.

11 Hazell SL, Hennessy WBH, Borody TJ, Carrick J, Brady L, Ralston M, Lee A. Campylobacter pyloridis gastritis II: distribution of bacteria and associated inflammation in the gastroduodenal environment. $\mathrm{Am} \mathrm{J}$ Gastroenterol 1987; 82: 297-301.

12 Ikeda K, Sonmnohe Y, Murayama H, Ikeda R, Inutsuta $\mathrm{S}$. Heterotopic gastric mucosa in the duodenum reaction to Congo Red under fiberoptic observation. Endoscopy 1982;14: 168-70.

13 Donoghue PE, Bombech CT. Yoshida I, Nyhus LM. The simplified endoscopic Congo Red test for completeness of vagotomy. Surg Gynecol Obstet 1986; 163: 287-9.

14 Cox DR. Analysis of binary data. London: Methuen, 1970 .

15 Lee A. Neglected niches: The microbial ecology of the gastrointestinal tract. In Marshall KC, ed. Advances in microbial ecology vol 8. New York: Plenum Press, $1985 ; 115-62$.

16 Willis RA. Some unusual heterotopias. Br Med J 1968; 3: $267-72$.

17 Wolff M. Heterotopic gastric epithelium in the rectum. A report of three new cases with a review of 87 cases of gastric heterotopia in the alimentary canal. Am J Clin Pathol 1971; 55: 604-16.

18 Tanemura H, Satumi U, Suzuki M, et al. Heterotopic gastric mucosa accompanied by aberrant pancreas in the duodenum. Am J Gastroenterol 1987; 82: 685-8.

19 Perera DR, Weinstein WM, Rubin CE. Small intestinal biopsy. Symposium of pathology of the gastrointestinal tract. Part III. Human Pathol 1975; 6: 157-214.

20 Taylor AL. The epithelial heterotopias of the alimentary tract. J Pathol 1927; 30: 415-49.

21 James AH. Gastric epithelium in the duodenum. (Fut 1964; 5: 28.5-94.
22 Hoedemaker $\mathrm{Ph} \mathbf{J}$. Heterotopic gastric mucosa in the duodenum. Digestion 1970; 3: 165-73.

23 Kreunig J, Bosman FJ, Kuiper G, Wal AM, Lindeman J. Gastric and duodenal mucosa in healthy individuals J Clin Pathol 1978; 31: 69-77.

24 Hazell SL, Lee A. Campylobacter pyloridis, urease, hydrogen ion back diffusion and gastric ulcer. Lancet 1986; ii: $15-77$.

25 Burdham KD, Perspectives in duodenal ulcer. London: Smith, Kline and French Laboratories Ltd, 1981: 18-23.

26 Patrick WJA, Denham D. Forest APM. Mucosal change in the human duodenum; a light and electron microscopic study and correlation with discase and gastric acid secretion. Gut 1974; 15: 767-76.

27 Leung FW, Andrew RD, Miller JC, Paulsen G, Guth $\mathrm{PH}$. Brunners glands protect overlying mucosa against acid injury. Gastroentrology 1987; 92: 1502.

28 Bendtsen F, Roenkilde-Gram BO, Tage-Jensen U, Oversen L, Rune S. Duodenal bulb acidity in patients with duodenal ulcer. Gastroenterology 1987; 93: 1263-9.

29 Terruzzi V. Gastric metaplasia of the duodenal bulb - a prospective endoscopic study. Endoscopy 1987; 19: 252-3.

30 Marshall BJ, Goodwin CS, Warren JR, et al. Longterm healing of gastritis and low duodenal ulcer relapse after eradication of $C$ pyloridis: a prospective double blind study. Gastroenterology 1987; 92: 1518.

31 Lambert JR, Borromeo M, Korman MG, Hansky J, Eaves ER. Effect of colloidal bismuth (DeNol) on healing and subsequent relapse of duodenal ulcers: role of Campylobacter pyloridis. Gastoentrology 1987; 92: 1489.

32 Coughlan G, Gilligan D, Humphries H, et al. Campylohacter pyloridis and relapse of duodenal ulcers. Gastroenterology 1987; 92: 1355. 